\section{Evaluation of the cardiovascular effects of vasicine, an alkaloid isolated from the leaves of Sida cordifolia L. (Malvaceae)}

Silveira, A.L.; Gomes, M.A.S.; Silva Filho, R.N.; Santos, M.R.V.; Medeiros, I.A.*; Barbosa Filho, J.M.

Laboratório de Tecnologia Farmacêutica, Universidade Federal da Paraíba

\section{Abstract}

The cardiovascular effects of vasicine, an alkaloid isolated from the leaves of Sida cordifolia L., were evaluated in this work. In non-anaesthetized rats $(n=6)$, vasicine $(1,2.5,5$ and $10 \mathrm{mg} / \mathrm{kg}$; i.v., randomly) induced hypotension associated with an intense bradycardia. Both responses were completely abolished after atropine (2 $\mathrm{mg} / \mathrm{Kg} ;$ i.v. $)$ and attenuated after hexamethonium ( $20 \mathrm{mg} /$ $\mathrm{Kg}$; i.v.). In isolated rat mesenteric artery rings, vasicine $(0.03,0.1,0.3,1,3,10,30,100$ and $300 \mu \mathrm{g} / \mathrm{mL}$, cumulatively) induced concentration-dependent relaxation of phenylephrine-induced tone $\left(\mathrm{IC}_{50}=3.8 \pm 0.9 \mu \mathrm{g} / \mathrm{mL}\right.$; $n=6$ ). In conclusion, the results show that vasicine produce hypotension and bradycardia which appears to be due to the stimulation of cardiac muscarinic receptors (directly and/or indirectly), and by a decrease of the peripheral resistances.

\section{Resumo}

Os efeitos cardiovasculares de vasicina, um alcalóide isolado das folhas de Sida cordifolia L., foi avaliado neste trabalho. Em ratos não-anestesiados $(\mathrm{n}=6)$, vasicina $(1,2.5,5$ e $10 \mathrm{mg} / \mathrm{kg}$; i.v., aleatoriamente) induziu hipotensão associada com uma intensa bradicardia. Ambas as respostas buscaram completamente abolidas após atropina ( $2 \mathrm{mg} / \mathrm{Kg}$; i.v. $)$ e atenuadas após hexamethonio ( $20 \mathrm{mg} / \mathrm{Kg}$; i.v.). Em anéis de artéria mesentérica de rato isolada, vasicina ( 0.03 , $0.1,0.3,1,3,10,30,100$ e $300 \mathrm{~g} / \mathrm{mL}$, cumulativamente) induziu relaxamento concentração-dependente de tônus promovido por fenilefrina (IC50=3.8 $0.9 \mathrm{~g} / \mathrm{mL} ; \mathrm{n}=6$ ). Em conclusão, os resultados mostram que vasicina produz hipotensão e bradicardia que parecem ser devidas à excitação de receptores muscarínicos cardíacos (direta e/ou indiretamente) e por uma diminuição das resistências periféricas.

Sida cordifolia L. (Malvaceae) is native specie of the Brazilian Northeast, popularly known as "Malva Branca". It is used in the folk medicine mainly as antirheumatic ${ }^{1}$, anti-inflammatory, analgesic ${ }^{2}$, antiasthmatic and in the treatment of nasal congestion ${ }^{3,4}$. In a pharmacological study performed in our laboratory, we demonstrated that the hydro alcoholic extract and the total alkaloid fraction (TAF) of this plant induced a marked hypotension associated with intense bradycardia. Chemical studies of the leaves of this plant revealed the presence of the quinazoline alkaloids vasicine, vasicinone and vasicinol ${ }^{5}$.

The alkaloids of $S$. cordifolia were mainly reported for their effect on the respiratory system ${ }^{6}$ and uterus $^{7}$, however, any detailed pharmacological investigation on its activity on the cardiovascular system in rats was found in the literature. Thus, the present study was aimed to isolate, identify and to evaluate the cardiovascular activity of vasicine, by using in vivo and in vitro approaches.

Table 1 show baseline values of MAP and HR in non-anaesthetized rats before (control) and after acute administration of atropine and hexamethonium.

Vasicine induced marked hypotension and intense bradycardia, which were completely abolished after administration of atropine (Figure 2), indicating that cardiac muscarinic receptors participate in this response. It is well established that the primary autonomic regulation of the sinoatrial node function is by vagal action through the stimulation of cardiac muscarinic receptors 10 . The stimulation of these receptors induces intense bradycardia and hypotension, mainly due to the decrease of cardiac output $^{10}$. Thus, we could suggest that vasicine could be acting, either directly in these receptors or indirectly via vagal activation, decreasing heart rate, cardiac output and consequently arterial pressure. This was investigated by using hexametonium, a ganglionic blocker, which was able to significantly attenuate, but not completely abolish, both hypotensive and bradycardic responses (Figure 2). 
The result suggests that vasicine induced hypotension and bradycardia could be mediated by two distinct pathways, a direct via activation of cardiac muscarinic receptors and indirectly, via vagal stimulation.

Another hypothesis explaining the hyotensive effect induced by vasicine could be a direct action of the alkaloid on the peripheral vascular resistances. In order to check the above hypothesis, we used the model of isolated superior mesenteric arteries. In these preparations, vasicine $(0.03-300 \mu \mathrm{g} / \mathrm{mL})$ induced concentration-dependent relaxation of phenylephrineinduced tone $\left(\mathrm{IC}_{50}=3.8 \pm 0.9 \mu \mathrm{g} / \mathrm{mL} ; \mathrm{n}=6\right)$ (Figure 3), suggesting that the decrease of peripheral total resistance is implicated in the vasicine-induced hypotension.

In conclusion, the results show that vasicine produce hypotension and bradycardia, which appears to be due to a direct and indirect stimulation of cardiac muscarinic receptors, and by a decrease of the total peripheral resistances. Moreover, taken together, the results suggest that the effects induced by both, the hydroalcoholic extract and the TAF appears to be mainly due to the presence of vasicine. However, further experiments are necessary to clearly elucidate the underlying mechanisms responsible for these responses.

Table 1. Baseline values of MAP and HR in nonanaesthetized rats before (control) and after, separately, acute administration of atropine $(2 \mathrm{mg} / \mathrm{kg}$, i.v.) and hexamethonium $(20 \mathrm{mg} / \mathrm{kg}$, i.v.). Values are mean \pm SEM of six experiments.

\begin{tabular}{llll}
\hline Parameter & Control & Afteratropine & $\begin{array}{l}\text { After } \\
\text { hexamethonium }\end{array}$ \\
\hline $\begin{array}{l}\text { MAP } \\
(\mathrm{mmHg})\end{array}$ & $116 \pm 1.9$ & $121 \pm 3.9$ & $94 \pm 9.3 *$ \\
$\mathrm{HR}(\mathrm{bpm})$ & $399 \pm 12$ & $499 \pm 27^{*}$ & $403 \pm 56$ \\
\hline
\end{tabular}

$* \mathrm{p}<0.05$ vs control.

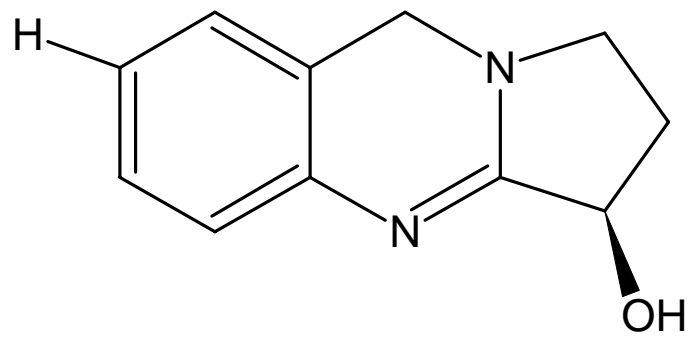

Figure 1. Chemical structure of vasicine
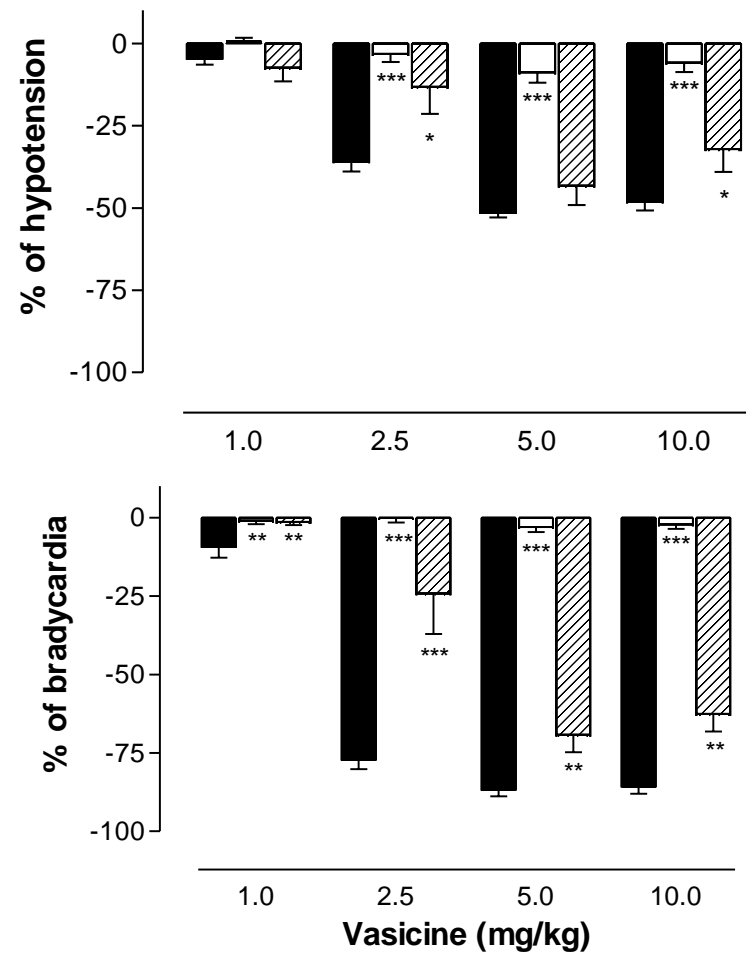

Control

$\square$ After atropine

ZIIA After hexamethonium

Figure 2. Vasicine-induced effects on MAP and HR in non-anaesthetized rats before (control) and after acute administration of atropine $(2 \mathrm{mg} / \mathrm{Kg}$, i.v.) or hexamethonium $(20 \mathrm{mg} / \mathrm{Kg}$, i.v.), separately. Values are mean \pm SEM of six experiments. $* \mathrm{p}<0.05$, ${ }^{*} * \mathrm{p}<0.01$ and $* * * \mathrm{p}<0.001$ vs control

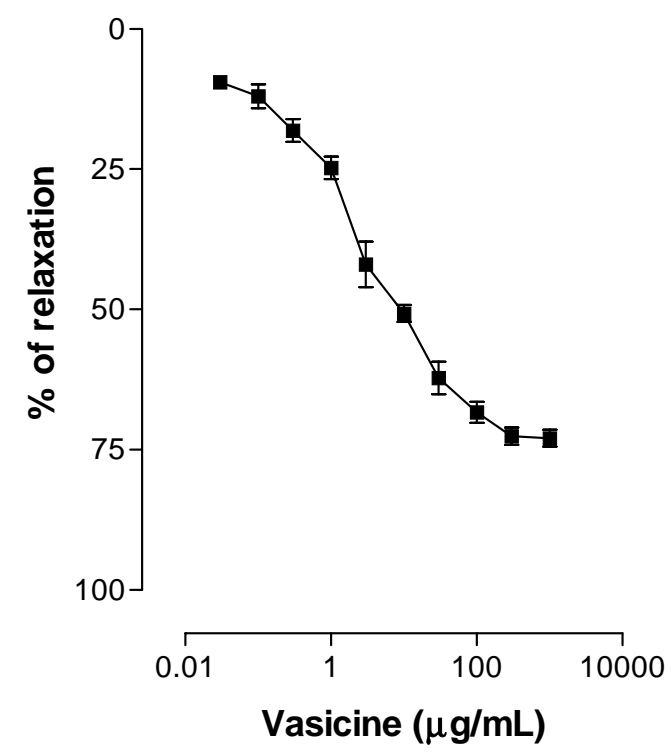

Figure 3. Concentration-response curves to vasicine in isolated rat superior mesenteric arteries pre-contracted with phenylephrine $(10 \mu \mathrm{M})$. Values are mean \pm SEM. of six experiments 


\section{Material and Methods}

S. cordifolia leaves (voucher specimen no. 30171, deposited in the herbarium of the Department of Biology of the Federal University of Sergipe, Brazil) were dried, pulverized and extracted with $95 \% \mathrm{EtOH}$ at room temperature for $72 \mathrm{~h}$. This extract, after being concentrated under vacuum, was dissolved in $3 \% \mathrm{HCl}$, filtered over celite and extracted several times with $\mathrm{CHCl}_{3}$. The $\mathrm{H}_{2} \mathrm{O}$ fraction was alkalinized with $\mathrm{NH}_{4} \mathrm{OH}$ to $\mathrm{pH} 9$ and extracted again with $\mathrm{CHCl}_{3}$. The $\mathrm{CHCl}_{3}$ fraction was washed with $\mathrm{H}_{2} \mathrm{O}$, dried $\left(\mathrm{Na}_{2} \mathrm{SO}_{4}\right)$ and the solvent evaporated to obtain the TAF, which was subjected to PTLC, and eluted with $\mathrm{CHCl}_{3}-\mathrm{MeOH}$ (9:1). From this procedure, vasicine (Figure 1) was isolated and solubilized in a mixture of distilled water/cremophor and used in pharmacological experiments.

Male Wistar rats (200-300 g) were used in all experiments. The mean arterial pressure (MAP) and heart rate (HR) was measured as described in Oliveira et al. ${ }^{8}$. The MAP and HR were recorded before (baseline values) and after administration of vasicine (1, 2.5, 5 and $10 \mathrm{mg} / \mathrm{Kg}$; i.v., randomly) and before and after atropine ( $2 \mathrm{mg} / \mathrm{Kg}$; i.v.; $15 \mathrm{~min}$.), a non-selective antagonist of muscarinic receptors, or hexamethonium $(20 \mathrm{mg} / \mathrm{Kg}$; i.v.; $30 \mathrm{~min}$.), a ganglionic blocker agent. The change of MAP and HR for each dose was expressed as percentage of baseline values. The rat superior mesenteric artery rings (1-2 $\mathrm{mm}$ ) were isolated according to the technique described by Tanaka et $a l .{ }^{9}$. The presence of functional endothelium was assessed by the ability of acetylcholine to evoke more than $80 \%$ of relaxation against phenylephrine-induced contractions.

Values are expressed as mean \pm SEM and student's t-test was performed to evaluate the differences between means. The $\mathrm{IC}_{50}$ value was calculated by non-linear regression by using Graph Pad Prism $^{\mathrm{TM}}$, version 3.0.

\section{Acknowledgements}

Sincere thanks to PRONEX/CNPq, CAPES and NAPRALERT.

\section{References}

${ }^{1}$ Muzaffer A, Joy S, Usmanu A.S. Screening of Sida cordifolia Linn, Sida rhomboidea L. and Triumfetta rotundifolia Lam. for anti-inflammatory and antipyretic activities. Indian Drugs, v.28, n.9, p.397, 1991.

${ }^{2}$ Franzotti E.M., Santos C.V.F., Rodrigues H.M.S.L., Mourão R.H.V., Andrade M.R., Antoniolli A.R. Antiinflammatory, analgesic activity and acute toxicity of Sida cordifolia L. (malva-branca). v.72, n.1/2, p.273-
278, 2000.

${ }^{3}$ Mukerji B. The Indian Pharmaceutical Codex. Volume I - Indigenous Drugs. Council of Scientific and Industrial Research, New Delhi, India, 1953.

${ }^{4}$ Ghosh S, Dutt A. The chemical examination of Sida cordifolia. J Indian Chem Soc., v.7, p.825, 1930.

${ }^{5}$ Ghosal S, Chauhan RBPS, Mehta R. Chemical constituents of Malvaceae. Part I. Alkaloids of Sida cordifolia.. Phytochemistry, v.14, p.830-832, 1975.

${ }^{6}$ Gunatilaka A., Sotheeswaran S., Balasubramaniam S., Chandrasekara A.I., Badra Sriyani H.T. Studies on medicinal plants of Sri Lanka. III. Pharmacologically important alkaloids of some Sida species. Planta Med., v.39, p.66-72, 1980.

${ }^{7}$ Gupta O.P., Sharma M.L., Ray Ghatak B.J., Atal C.K. Potent uterine activity of alkaloid vasicine. Indian J Med Res., v.66, p.865-871, 1977.

${ }^{8}$ Oliveira E.J., Medeiros I.A., Mukeierjee R. Hypotensive and spasmolytic effects of normacusine B from Strychnos atlantica root. Phytomedicine, v.3, p.4549, 1996.

${ }^{9}$ Tanaka Y., Mochizuki Y., Tanaka H., Shigenobu K. Significant role of neuronal non-N-type calcium channels in the sympathetic neurogenic contraction of rat mesenteric artery. Br. J. Pharmacol., v.128, p.16021608, 1999.

${ }^{10}$ Peterson G.L., Herron G.S., Yamaki M., Fulllerton D.S., Schimerlik M.I. Purification of the muscarinic acetylcholine receptor from porcine atria. Proc Natl Acad Sci U S A., v.81, p.4993-4997, 1984.

\section{* Autor para correspondência}

Isac A. de Medeiros

Laboratório de Tecnologia Farmacêutica

Universidade Federal da Paraíba

Caixa Postal 5009 - CEP 58.051-970

João Pessoa - PB - Brazil

E-mail: isacmed@uol.com.br 